\title{
Gode pædagogiske praksisser
}

Den 14. årlige DUN konference, som løb af stabelen 19.-20. juni i år, handlede om feedback og gode undervisningspraksisser. På konferencens anden dag præsenterede en lang række danske universitetsundervisere, universitetspædagoger og universitetsadministratorer deres gode pædagogiske praksisser - især mht. feedback på studerendes arbejde.

Det var en god konference, både hvad angår fagligt indhold, erfaringsudveksling og netværksdannelse, og vi i redaktionen vil gerne med dette nummer af Dansk Universitetspædagogisk Tidsskrift forsøge at fastholde noget af den viden og de erfaringer, som blev præsenteret på konferencen. Fastholdelsen og vidensdelingen er til gavn både for deltagere på konferencen, som måtte fravælge nogle sessionsoplæg pga. andre, samtidige gode oplæg, og for DUN-medlemmer, som desværre ikke kunne deltage i konferencen $i$ år.

Dette nummer af tidsskriftet indeholder således 5 bidrag fra oplægsholdere, hvor nogle har skrevet videnskabelige artikler med tilhørende peer-review, og nogle har skrevet faglige artikler, som er blevet kommenteret af redaktionen. Fælles for disse artikler er dog, at de alle er om- og videreskrivninger af oplæg, som de blev præsenteret på konferencen, tilsat de overvejelser, præciseringer og nuanceringer, som uvægerligt fremkommer af at have været præsenteret for og diskuteret med konferencedeltagere. Konferencens deltagere kan derfor betragte sig selv som første review-lag for disse artikler - og det er artiklerne selvfølgelig kun blevet mere interessante af!

Christian S. Høyers artikel, Feedback og debriefing, tematiserer begrebet debriefing som en særlig form for feedback, der kan styrke deltagernes læring efter simulationsøvelser. CSH gennemgår dels begrebet debriefing og dels en række principper for gennemførelse af debriefing, herunder anbefalinger til strukturering og til facilitatorens rolle. Afslutningsvist skitserer forfatteren tre cases, der reflekterer hans personlige erfaringer i facilitatorrollen under debriefing af yngre læger. Casene er hentet fra et konkret simulationsforsøg med genoplivning $i$ en ambulance.

En anden feedbackform er i fokus hos Lene Tortzen Bager, som i sin artikel, Cafemodellen: anerkendende feedback i projektgrupper, beskriver, hvilke grundprincipper der ligger bag cafemodellen, og hvordan den gennemføres i praksis. Derudover formidler LTB sine erfaringer med at anvende cafemodellen i forbindelse med projektarbejde på en nystartet kandidatuddannelse ved Nordisk Institut på Aarhus Universitet. Artiklen afsluttes med en refleksion og perspektivering af disse erfaringer $i$ lyset af de studerendes evaluering og idealer om læring i faglige praksisfællesskaber.

Der er ligeledes tale om faglige praksisfællesskaber, når Hanne Nexø Jensen $\mathrm{i}$ artiklen, Ja tak til mere kollektiv opgave- og skrivevejledning, argumenterer på baggrund af sine erfaringer med kollektiv vejledning på bachelorprojekter og specialer og den bagvedliggende læringsforståelse for, hvordan de studerendes læring faktisk øges, når skrive- og opgavevejledningen kollektiviseres. HNJ runder af med forslag til, hvordan underviserne kan gennemføre kollektiv vejledning.

Karen M. Lauridsens artikel, Hjernen er ikke en krukke der skal fyldes, men en ild der skal tændes, omhandler også, hvordan de studerendes læring ved vejledning kan øges, idet den beskriver, hvordan man på Learning Styles Lab (Handelshøjskolen, Aarhus Universitet) på grundlag af Dunn og Dunns læringsstilbegreb arbejder med at styrke både lærernes vejlederkompetencer og de studerendes udbytte af vejledningen. KML kommer til sidst med sin vurdering af projektet og sine bud på, hvordan andre kan overføre praksis og resultater til egen vejledning.

I Jane Nielsen, Tejs Vegge og Pernille Anderssons artikel, Undervisning i ingeniørarbejde, indgår overvejelser om feedback også i det nyudviklede introduktionskursus på forste år af Fysik og Nanoteknologi bacheloruddannelsen på DTU, som forfatterne beskriver. Kursets formål er at give et overblik over studiets 
faglige muligheder og perspektiver samt ved hjælp af faglige udfordringer og eksperimenterende undervisning, eksempelvis eksperimentelle øvelser på moderne udstyr og computersimuleringer med software, understøtte de studerendes motivation. Erfaringerne er, at de studerende på trods af høj arbejdsbelastning generelt var glade for forløbet og fandt, at emner og aktiviteter samt koblingen til grundfagene var gode. Herved føler de sig bedre rustede til at vælge kurser fremover.

Vi synes i redaktionen, at disse artikler er vigtige vidnesbyrd, ikke kun som dokumentation af konferencen, men også om, at der rundt omkring i mangen universitetspædagogisk sammenhæng foregår spændende udvikling af undervisning og uddannelse.Vi håber naturligvis, at der i forbindelse med næste konference er flere af oplægsholderne, som vil tage op- og udfordringen op om at skrive en artikel til Dansk Universitetspædagogisk Tidsskrift på baggrund af deres oplæg.

Herudover bringer vi i dette nummer af tidsskriftet to indlæg, der ikke som sådan udspringer af konferencen. Alligevel knytter de hver især an til temaet om feedback.

Jane Vinther beskriver i sin artikel, Visual Interactive Syntax Learning, hvordan man på Syddansk Universitet har udarbejdet et computerprogram, som kan hjælpe studerende til at opøve deres syntaktiske færdigheder i engelsk. Et aspekt af computerprogrammets force er, at det kan give den studerende en øjeblikkelig feedback om vedkommendes aktuelle færdigheder og potentielle udviklingsbehov. Anvendelsen af VISL i kombination med mere traditionelle forelæsningsrækker giver ifølge JV bedre og bredere læring af engelsk grammatik, idet web-baserede undervisningsmetoder i højere grad tilgodeser de studerendes ønske om og behov for individuelle læringsværktøjer.

Stig Børsen Hansens debatindlæg, Asynkron e-læring: skriften på nettet?, er så at sige en slags feedback i sig selv. Stig er blevet inspireret af en tidligere artikel i dette tidsskrift og vil med indlægget her vise, hvordan Marx' analyse af teknologi kan bidrage til belysningen af IT-baserede læreprocesser. IT-skeptikere har med Marx advaret mod risikoen for en deprofessionalisering, men som SBH afsluttende husker os på, så er teknologisk udvikling ikke en givethed og kan derfor præges og anvendes i en ønskelig retning, bare de forskellige aktører er opmærksomme på de muligheder og farer, der kan ligge i en given teknologi.

Denne slags indlæg, som på den ene eller anden måde opponerer, understøtter, udvider eller refererer til tidligere artikler, ser vi på redaktionen gerne mange flere af - også gerne i form af kommentarer, kronikker eller artikler.

Og når nu konferencens - og dermed også dette konferencenummers - tema er feedback, så vil vi fra redaktionens side til slut gerne viderebringe en lille "skåltale", som kan bruges ved festlige universitetspædagogiske lejligheder:
Vi kender alle K'erne for god kritik, men ...

Der er også K'er til

Ond kritik - den skal vere

kras krigerisk konfliktsegende knurrende konfronterende

Der er K'er til ubehjelpsom kritik

kikset kluntet klodset knubbet kejtet

Afmålt kritik - jeg anbefaler, at den er

kold karrig kynisk kronisk kalkuleret

Pinlig kritik kan blive

Kitchet klistret kloeg kvalm klam

Men er man den oversøde type, kan man levere kak kåd kry kelen kramme-kritik

Engang dyrkede mange

kollektiv kommunistisk kulturel konsbevidst kapitalundergravende kritik

men verst er måske de 5 K'er for ligegyldig kritik kønslos kysk kedelig kunstig klinisk

Den helt odelaggende kritik skal opfylde kravet om at vere

kronkende kolerisk krovende knusende katastrofal

Mens kritik med flere dagsordner bliver

kompromitterende konkurrerende klynkende konspiratorisk korrupt

Indestangt kritik kan genkendes på at vere knap kontrollerende knugende kantet kritisabel.

De 5 K'er for kritikere

klog kvalificeret kyndig karakterfast knivskarp

som

koncentreret kort og klart

kan levere

karismatisk kommunikativ kickstartende kanon-kritik

(Rikke von Müllen, 2008)

Deadlines for de kommende numre af Dansk Universitetspædagogisk Tidsskrift kan findes på hjemmesiden, www.dun-net.dk/tidsskrift, hvor også retningslinjer og manuskriptvejledninger ligger. Send dit artikelforslag tildut@dun-net.dk. God skrive-og læselyst! 